\title{
Verification of the Performance Model in Selected Companies in the Mining Industry
}

\author{
Eduard HYRÁNEK ${ }^{1 *}$, Monika KOWALSKA-SUDYKA ${ }^{2}$, Branislav MIŠOTA ${ }^{3}$, \\ Ivana ONDREJMIŠKOVÁ ${ }^{4}$ and Martin KAPKO
}

\begin{abstract}
Authors' affiliations and addresses:
${ }^{1}$ University of Economics in Bratislava, Faculty of Business Management, Dolnozemská cesta 1, 85235 Bratislava, Slovakia

e-mail: eduard.hyranek@euba.sk

${ }^{2}$ Road and Bridge Research Institute, Instytutowa Street 1, 03-302 Warszawa, Poland e-mail: mkowalska@ibdim.edu.pl

${ }^{3}$ Slovak University of Technology in Bratislava, Institute of Management, Vazovova 5, 81243

Bratislava, Slovakia

e-mail: branislav.misota@stuba.sk

${ }^{4}$ Department of Safety Studies, Faculty of Political Science and International Relations, Matej Bel University in Banská Bystrica, Kuzmányho 1, 97401 Banská Bystrica, Slovakia e-mail: ivana.ondrejmiskova@umb.sk

${ }^{5}$ Technical University in Kosice, Institute of Earth Resources, Faculty of Mining, Ecology, Process Control and Geotechnologies, Park Komenského 19, 042000 Košice, Slovakia e-mail: martin.kapko@tuke.sk
\end{abstract}

*Correspondence:

Eduard Hyránek, University of Economics in Bratislava, Faculty of Business Management, Dolnozemská cesta 1, 85235 Bratislava, Slovakia tel.: +421267295669

e-mail: eduard.hyranek@euba.sk

Funding information:

This research was funded by MŠVVaŠ SR

Grant Number VEGA 1/0462/19

How to cite this article:

Hyránek, E., Kowalska-Sudykam., Mišota, B., Ondrejmišková, I. and Kapko, M. (2021).

Verification of the Performance Model in

Selected Companies in the Mining Industry. Acta Montanistica Slovaca, Volume 26 (3), 415-426

DOI:

https://doi.org/10.46544/AMS.v26i3.03

\begin{abstract}
The paper describes the HGN performance model and its verification at four selected mining companies from the results of 2020 . We abstract from the predictive ability of the HGN model. The analysis focuses on the impact of one of the six indicators affecting the efficiency and overall financial performance of the company to generalize the findings of this analysis. We focused on the potential possibilities of modifying one of the indicators affecting efficiency as part of the evaluation of the company's financial performance by applying it to selected companies in the mining industry. It confirms the hypothesis, which assumes a more objective impact on the evaluation of efficiency by including the asset in its acquisition price compared to the asset in the residual price. In other woords, the hypothesis of the need to include the asset in its total volume in its acquisition price was confirmed. This is vitally important for a more objective assessment of efficiency and for better comparisons between companies. The residual price would improve turnover and thus the performance of companies with outdated technical and technological equipment. More fundamental changes in the content of some indicators entering the HGN model will also require a reassessment of the performance interval.
\end{abstract}

\section{Keywords}

Business efficiency, financial performance, HGN model, efficiency indicators, efficiency-reducing indicators, synthetic indicator, asset turnover.

(c) 2021 by the authors. Submitted for possible open access publication under the terms and conditions of the Creative Commons Attribution (CC BY) license (http://creativecommons.org/licenses/by/4.0/). 


\section{Introduction}

The mining sector is an important part of the Slovak economy and this sector needs to be given increased attention, as it is also related to important economic areas such as green competitiveness, green growth and sustainable development (Andryeyeva et al., 2021; Nassar \& Tvaronavičiené, 2021). The mining industry is composed of manufacturing companies operating in essentially the same way, whether during the period under standard conditions or under conditions influenced by standard environmental and health degrees connected with the ongoing coronavirus crisis (Rebhun, 2021; Stefko et al., 2021). The reason for that might be related with innovative posture (Ključnikov et al., 2021) and financing opportunities that manufacturing firms have (Civelek et al., 2021). We do not officially record any fundamental differences in the achieved volumes of sales and profit of the surveyed companies during the years 2019 and 2020, and for this reason we can consider them compatible for the purposes of our research. Gradually while doing the research, we were able to verify the influence of individual determinants influencing financial performance. Although some studies also emphasize the impact of individual characteristics on financial purposes (Ključnikov et al., 2019; Ključnikov et al., 2020a; Ključnikov et al., 2020b; Dvorsky et al., 2021a; Okpamen \& Ogbeide, 2020) and other studies also highlight the performance of Slovak firms depending on their efficiency (Čabinová et al., 2021), economic conditions (Dvorský et al., 2019; Štefko et al., 2020), the usage of marketing tools (Civelek et al., 2020), corporate social responsibility (Metzker \& Zvarikova, 2021) and e-commerce activities (Horvath et al., 2021), different from these studies, we verified the determinants by evaluating the financial performance using an innovative model. In order to achieve the maximum possible objectivity of a company's performance assessment, we verify the model for the state of affairs of various companies within the industry, in order to identify specific factors and their impact.

In this paper we deal with issues related to the evaluation of financial performance using the HGN model (acronym for the initials of the authors of the model Hyránek, Grell, Nagy). We declare this using a set of four companies, where we will verify the explanatory power of the model and look for ways to improve it.

\section{Literature Review}

The mining industry has a great influence on the whole society, not only from an economic point of view. According to Ranangen and Lindman (2017), the mining industry is experiencing a good economic period. It is usually necessary to recultivate the mine after the completion of mining activities and thus return the landscape to its nature. In the case of quarries, these are reclamations by flooding, thus creating a nature-friendly habitat for animals. Ideally, this area will be used for fish production. It can also help fishing companies from an economic point of view. In this context, Sagapova and Gulyás (2021) addressed the financial performance of fishing companies. This intervention in the landscape also has a major impact on the hydrological conditions in the wider area. Fanta (2019) dealt with the analysis of economic efficiency and social responsibility of companies operating in the field of water resources management. It focused mainly on indicators such as the number of owners and operators of water management services, but also issues in the field of water loss from river basins, water consumption by consumers or the number of wastewater treatment plants. Zhou (2013) points out that hard coal mining in the mining industry is most often associated with environmental pollution, which includes water environment, surrounding rock environment, stress environment, thermal environment, active faults, etc. Tubis et al. (2020) dealt with risk assessment in the mining industry. According to their evaluation, in the case of risk management, it is necessary to take into account risks of an environmental and economic nature. He et al. (2017) state that both types of these risks can be negative effects caused by finances, which play an important role in supporting economic growth, and therefore governments always strongly support the financial industry. According to the authors who tested the extended STIRPAT model as to whether finances significantly affect pollution levels, pollution abatement policies should be designed in relation to finances. Kuzmanovic et al. (2011) include among the risks a risk of a social nature.

Baatartogtokh et al. (2018) examined the use of outsourcing by companies operating in the mining industry. Although outsourcing is an attractive way to increase the financial performance of a mining company, outsourcing is very problematic due to the specificity of the whole industry. In the case of the mining industry, it is therefore not feasible for a mining company to become just a management company for several dozen outsourcing service providers. In this sector, it is therefore rather common that outsourcing is applied here only depending on specific situations that need to be addressed from a strategic point of view in the company. If outsourcing services are used excessively, the innovative development in the company could be stopped. According to Vokoun (2017), however, economic innovations themselves require knowledge of economic history and an interdisciplinary approach. The correct identification of a good innovative approach in society is not always unambiguous, so it is always better to compare the two chosen innovative approaches and continue to innovate the company according to this direction (Kliestik et al., 2020). According to Ludbrook et al. (2019), intelligent manufacturing processes, digitization of manufacturing systems and data-based decision-making are essential for sustainable innovation in the age of Industry 4.0. According to Sanchez and Hartlieb (2020), the process of innovation is very crucial for companies 
operating in the mining industry, because thanks to innovations, especially technological, they are able to mine at greater depths, are able to penetrate harder materials and thus reach more minerals, raw materials. The fundamental positive impact of innovations in the mining industry is also confirmed by Kasych et al. (2019), who examined the emission volumes of pollutants from Ukrainian mining companies into the air. They found that it is important to introduce cleaner production technologies, waste-free technologies and other innovations in order to achieve low levels of these emissions, and thus sustainable development. Innovations today are accompanied by information and communication technologies (ICT) in almost every industry. According to Moczulski et al. (2016), modern ICT in the mining industry is very welcome, as it can be used to automatically adjust mining processes, mining speed, estimate the load of belt conveyors, etc. The significant influence of ICT is also confirmed by Kearney et al. (2019) presenting the idea that the Internet of Things and related large data applications are a tool in introducing and improving the functioning of environmentally sustainable progress, or Suler et al. (2021) devoted to digitized mass production and sustainable performance of society through the Internet of Things.

The value of a company is a crucial aspect in every sector, including the mining sector, and can be assessed from several perspectives, such as financial or socioemotional (Bacik et al., 2019; Jurásek et al., 2021; Janovac et al., 2021). To verify the performance of mining companies, according to Vochozka et al. (2016) serve well the basic financial analysis, and according to Vrbka and Rowland (2019) also more advanced methods of comprehensive evaluation of the company - especially creditworthiness and bankruptcy models and economic value added (EVA). The authors evaluated the financial health of the average mining company in the Czech Republic for the period 2012-2016, using several well-known bankruptcy and creditworthiness models and EVA in two variants. They found that mining companies in the Czech Republic are not financially sound; it is possible to correct negative phenomena that characterize the whole industry. The conditions of the business environment, risk management, size and age of enterprises, or social responsibility to operate with an emphasis on environmental sustainability can also play an important role in this problem (Belas et al., 2020; Çera et al., 2020; Dvorsky et al., 2021b; Gavurova et al., 2020; Pana et al. 2018). Vochozka and Psarska (2016), in turn, looked for key factors that support the growth of value added and its possible changes in selected countries and small and medium-sized enterprises in the EU in the context of possible positive development of value added. According to Sierpinska and Kustra (2008), the financial performance of the company is influenced by the system of remuneration of employees in all sectors. In the case of the mining sector, they recommend that workers' remuneration be 15-20\% of the basic wage. It is also important to mention joint-stock companies operating in the mining industry, where they have a great influence on the value of their shares of any adverse event, such as accidents, etc. the mining industry is directly or indirectly linked (Zheng and Li, 2008). The share price can be predicted according to Vochozka et al. (2020a) using artificial neural networks. The authors generated Multilayer Perceptron Networks (MLP) and Radial Basis Function networks (RBF), as well as Support Vector Regression (SVR) and Back-Propagation Neural Network (BPNN) and found which forms of neural networks are best for predicting the share price of a particular company applicable in practice. Similarly, Machova and Vochozka (2019) or Suler et al. (2020) also used neural networks to predict the share prices of a particular mining company. Artificial neural networks can also be used for the overall assessment of creditworthiness or for predicting the possible bankruptcy of the company. This was proved by Vochozka et al. (2020b), who used long short-term memory (LSTM) networks to create a model for predicting corporate bankruptcy, or Horak et al. (2020), who demonstrated the applicability of basic MLP networks for a similar purpose, comparing the results with the Support Vector Machine (SVM) model, which achieved relatively high accuracy but is not applicable in the structure of correct classification. It is neural networks, or artificial intelligence and machine learning, that can help create sustainable values and improve operational performance, and these intelligent technologies are essential in the mining industry in Industry 4.0 and the already anticipated Industry 5.0 (Whittle et al., 2019).

At the end of this section, it should be emphasized that the improvements in any area of a country's life may be reflected in its economic prosperity (Čižo et al., 2020; Gavurova et al., 2021). In this way, the research community should focus on various important aspects with the potential to improve economic conditions (Halaskova et al., 2020). The mining industry is no exception, where a skilled workforce is also needed (Př́ivara et al., 2020. Therefore, it is desirable to examine this sector from every perspective. This study presents a microeconomic financial perspective.

\section{Material and Methods}

The objective of this paper is to assess the financial performance of selected companies in the mining industry using the HGN model (acronym for the initials of the authors of the model Hyránek, Grell, Nagy) and to confirm its application in the performance of non-financial companies. The results allow us to compare different modifications of the model so that it can ultimately be compiled in the optimal version for different types of companies.

For the purposes of verification, we apply commonly used methods, especially statistical methods and analysis of financial ratios. Selected companies from the mining industry, on which we will verify the HGN model, 
are EUROVIA - Kameňolomy, s.r.o., KSR - Kameňolomy SR, s.r.o., AMETYS s.r.o. Košice and VSK MINERAL s.r.o. These are four enterprises from a branch belonging to the number according to SK NACE 08.11.0. - Mining of decorative and building stone, limestone, gypsum, chalk and slate. All four companies achieve revenues of more than 5 mil. Eur. After processing a routine financial analysis of several companies in the sector, we concluded from the results obtained from the financial statements for 2020 that they represent suitable models for the needs of research within the HGN model.

\section{Current status}

A number of different approaches have been published in business performance modeling (e.g., Altman, \& Saunders, 1997). The results of previous research and the application of the HGN model and its modifications confirm its usability for the needs of assessing the financial situation, with respect to business performance and also for evaluating business prediction (Hyránek et al., 2014; Grell \& Hyránek, 2012; Hyránek, 2012). From the results obtained so far by applying a model based on the economic data of several companies, the objectivity of the evaluation of the company's performance was demonstrated (Hyránek et al., 2017; Hyránek et al., 2018). However, we are continuing our research in order to improve the model by modifying either individual financial ratios or setting performance intervals depending on the nature of the company.

Model HGN. The initial results of the HGN model are based on the processed database of financial statements of 260 non-financial business entities of legal entities in the Slovak Republic (Hyránek et al., 2014; Grell \& Hyránek, 2012; Hyránek, 2012) and also from 100 large companies (Hyránek et al., 2017; Hyranek et al., 2018). The database of 100 large companies was based on the financial statements of double-entry bookkeeping for the years 2013 to 2017. As part of the research, we are gradually finding out that some original financial ratios need to be modified or completely substituted in order to measure performance more objectively. In this paper, we will apply the basic version of the model and assess the impact of one indicator affecting financial performance. We will verify the operation of the indicator at four non-financial manufacturing companies in the extractive industries.

Basic characteristics of the HGN model. The basic indicators contained in the initial HGN model are as follows:

- Efficiency indicators xi: Return on equity - $x_{1}$, Share of cash flow in sales - $x_{2}$, Turnover of total assets $x_{3}$.

- Indicators reducing efficiency: $y_{i}$ : Binding of short-term receivables $y_{1}$, Repayment period of long-term foreign capital $-y_{2}$, Operating costs $-y_{3}$.

These are two groups of financial ratios commonly used in financial analysis. One group contains three efficiency indicators $\left(x_{i}\right)$ and the other group will contain three efficiency indicators (yi.). We synthesized the indicators into one comprehensive synthetic performance indicator so that it shows the financial situation of the company with the focus on performance as objectively as possible.

At the same time, the synthetic indicator makes it possible to compare the financial results of companies, with respect to their performance.

By adding the values of the indicators in the individual groups, we can obtain an aggregate efficiency indicator xi and an aggregate indicator lowering efficiency $y i$. These aggregate indicators will provide us with partial results on the company's performance in terms of efficiency and effectiveness. In principle, we can summarize that, in addition to one indicator, there are homogeneous indicators that are not contradictory or mutually exclusive. An exception to this is the indicator Repayment period of long-term borrowings, which put emphasis on the debt situation of the company. The amount of long-term debts fundamentally affects the final value of the synthetic indicator. The number of repayment periods is shown in the indicator in years. For other indicators, the resulting value is expressed by a coefficient.

Aggregate efficiency indicator (AEI) $x_{i}$ :

$\sum_{i=1}^{3} x_{i}$

will provide a partial picture of the company's performance in terms of efficiency.

Aggregate indicator lowering efficiency (AILE) $y_{i}$ :

$\sum_{i=1}^{3} y_{i}$

will provide a partial picture of the company's performance in terms of complexity.

Since the indicators $x_{i}$ express efficiency, it is desirable that their final values be as high as possible and the indicators $y_{i}$, which have an impact on the reduction of efficiency, have a final value as low as possible. These two groups of indicators, i.e. aggregated efficiency indicators $x_{i}$ and aggregated efficiency indicators $y_{i}$ individually 
give only a partial picture of the company's performance and that is insufficient for us. They evaluate only the partial financial situation and the overall performance of the company. We need a more comprehensive view of business performance. If we adjust the aggregate efficiency indicator $x_{i}$ by the agregate indicator lowering efficiency $y_{i}$, we will obtain a synthetic indicator (SI), in which the values of all six indicators will be projected. Based on the above, we define the resulting synthetic indicator within the model as follows:

$$
S U=\sum_{i=1}^{3} x_{i}-\sum_{i=1}^{3} y_{i}
$$

Application of the model in the environment of economic objects, i.e., profitable non-financial corporations, also requires determining the explanatory power of the Synthetic Indicator (hereinafter only SI) in terms of performance. It follows logically from the method of calculation and the content of individual indicators that the company with the highest $S U$ value should be the best. The question remains, to what extent is the resulting value of SU for the performance of the company still bearable, resp. minimal. To analyze this problem, we used an adequate mathematical graded apparatus that allowed us to determine the following performance intervals (Tab. $1)$.

\begin{tabular}{|c|c|c|c|}
\hline$\infty$ to $-6,5$ & -6.5 to -2.7 & -2.7 to -0.1 & -0.1 to $\infty$ \\
\hline Weak & Below average & Average & Above average \\
\hline
\end{tabular}

\section{Results}

We present the results of our work on the following application of the financial performance model HGN. It comprised of a set of four companies operating in the decorative stone mining industry, part of the mining industry. All data for the needs of individual calculations are obtained from generally available sources published in the Register of financial statements, and from data processed by the company FIN STAT s.r.o. While processing all the necessary analyses, we relied on these official publicly available data, which did not require consent for the publication of the results from the surveyed companies.

In Tables 2 and 3, we present the most currently available selected, absolute indicators from the company's balance sheet for the year 2020. We do not evaluate the development using a time period, but use only one accounting period for the year 2020.These absolute indicators are the basis for the calculations of financially named indicators as determinants that influence the results obtained using the performance model HGN.

Tab. 2. Data from the company's financial statements for the year 2020 - Assets

Assets

Data from the financial statements (in thousands of euro)

\begin{tabular}{l|rrrr}
\hline & $\begin{array}{r}\text { EUROVIA - Kameňolomy, } \\
\text { s.r.o. }\end{array}$ & $\begin{array}{c}\text { KSR - Kameňolomy SR, } \\
\text { s.r.o. }\end{array}$ & $\begin{array}{c}\text { AMETYS } \\
\text { s.r.o. }\end{array}$ & \multicolumn{2}{c}{ VSK MINERAL } \\
s.r.o.
\end{tabular}

Tab. 3. Data from the company's financial statements for the year 2020 - Liabilities

\section{Liabilities}

\begin{tabular}{|c|c|c|c|c|}
\hline \multicolumn{5}{|c|}{ Data from the financial statements (in thousands of euro) } \\
\hline & $\begin{array}{c}\text { EUROVIA - Kameňolomy, } \\
\text { s.r.o. }\end{array}$ & $\begin{array}{l}\text { KSR - Kameňolomy SR, } \\
\text { s.r.o. }\end{array}$ & $\begin{array}{l}\text { AMETYS } \\
\text { s.r.o. }\end{array}$ & $\begin{array}{l}\text { VSK MINERAL } \\
\text { s.r.o. }\end{array}$ \\
\hline Equity & $9,478.10$ & $9,933.75$ & $1,024.48$ & $6,942.83$ \\
\hline $\begin{array}{l}\text { Profit per account. period } \\
\text { after tax }\end{array}$ & 767.95 & -100.72 & 599.82 & 600.90 \\
\hline Liabilities & $6,953.29$ & $3,317.09$ & $3,866.46$ & $7,163.54$ \\
\hline Long - term liabilities & 19.56 & 0.02 & $2,215.14$ & $3,142.43$ \\
\hline Long - term bank loans & 0 & 0 & 0 & 0 \\
\hline Short-term liabilities & $2,145.52$ & $2,729.55$ & 961.82 & $1,423.46$ \\
\hline
\end{tabular}

In Table 4, we present selected absolute indicators from the profit and loss statement of enterprises that enter into the calculations of the ratios of the determinants of the HGN performance model. 
Tab. 4. Data from the company's financial statements for the year 2020 - Profit and Loss

\section{Profit and Loss}

\begin{tabular}{|c|c|c|c|c|}
\hline \multicolumn{5}{|c|}{ Data from the financial statements (in thousands of euro) } \\
\hline & $\begin{array}{c}\text { EUROVIA - Kameňolomy, } \\
\text { s.r.o. }\end{array}$ & $\begin{array}{c}\text { KSR - Kameňolomy } \\
\text { SR, s.r.o. }\end{array}$ & $\begin{array}{l}\text { AMETYS } \\
\text { s.r.o. }\end{array}$ & $\begin{array}{l}\text { VSK MINERAL } \\
\text { s.r.o. } \\
\end{array}$ \\
\hline Total sales & $12,855.75$ & $8,970.05$ & $8,288.32$ & $7,935.88$ \\
\hline Sales of goods & 0.00 & 388.72 & 37.85 & 45.11 \\
\hline Revenues from sales of own products & $11,996.14$ & $7,979.56$ & $7,880.82$ & $7,261.28$ \\
\hline Revenues from sales of services & 859.62 & 601.77 & 369.65 & 629.49 \\
\hline Depreciation & $1,467.78$ & 661.92 & 641.42 & 763.42 \\
\hline Value added & $5,364.24$ & $1,338.68$ & $2,277.55$ & $3,474.42$ \\
\hline Costs without depreciation & $10,243.13$ & $12,685.14$ & $6,083.43$ & $6,540.90$ \\
\hline
\end{tabular}

The data in Table 4 confirm that in terms of the volume of sales achieved, there are four comparable companies. The volume of revenue extends from about 7.9 thousand. Euro up to 12.9 thousand Euro. The differences in sales volumes of the individual companies, with the exception of EUROVIA, are not significant. Furthermore the achieved net profit, whether the absolute volume (approx. 700 euros) or the profitability of sales (approx. $7 \%$ ) with the exception of KSR - Kameňolomy SR with the achieved loss, is comparable. Based on the composition of the total achieved sales, we can state that they are decisively engaged in the production and sale of our own products, which comprise $89 \%$ to $95 \%$ in total. It would not be appropriate to use a model to compare companies with a different method of core business. Undertakings engaged in the sale of goods or provision of services may have a significantly different ownership structure than manufacturing undertakings, and furthermore the resulting turnover of assets, which will be the focal point of interest in this article as well. Of course, for nonmanufacturing enterprises there are other differences, which are reflected in the values of indicators, such as. profitability, volume of receivables, cash flows, etc, however we do not evaluate these in this article.

Tables 5 and 6 show the relative financial indicators of the surveyed companies calculated from the absolute data contained in the financial statements for the year 2020. These indicators are part of the HGN model in group $x_{i}$, i. indicators that reduce efficiency and in group $y_{i}$, i.e., efficiency indicators. We count the indicators numerically to 4 decimal places.

Tab. 5. Financial efficiency ratios $\left(x_{1}-x_{3}\right)$

\begin{tabular}{l|cccc}
\hline & $\begin{array}{c}\text { EUROVIA - Kameňolomy, } \\
\text { s.r.o. }\end{array}$ & $\begin{array}{c}\text { KSR - Kameňolomy SR, } \\
\text { s.r.o. }\end{array}$ & $\begin{array}{c}\text { AMETYS } \\
\text { s.r.o. }\end{array}$ & $\begin{array}{c}\text { VSK MINERAL } \\
\text { s.r.o. }\end{array}$ \\
\hline$x_{l}$ Return on equity & 0.0810 & 0.0000 & 0.5855 & 0.0866 \\
$x_{2}$ Share of cash flow in sales & 0.1739 & 0.0738 & 0.1498 & 0.1719 \\
$x_{3 a}$ Turnover of net assets & 0.7824 & 0.6769 & 1.6946 & 0.5626 \\
$x_{3 b}$ Turnover of gross assets & 0.3321 & 0.3361 & 0.8978 & 0.3485 \\
\hline
\end{tabular}

Tab. 6. Financial efficiency ratios $\left(y_{1}-y_{3}\right)$

\begin{tabular}{l|cccc}
\hline & \multicolumn{1}{c}{ Tab. 6. Financial efficiency ratios $\left(y_{1}-y_{3}\right)$} & & \\
& $\begin{array}{c}\text { EUROVIA - } \\
\text { Kameňolomy, s.r.o. }\end{array}$ & $\begin{array}{c}\text { KSR - Kameňolomy } \\
\text { SR, s.r.o. }\end{array}$ & $\begin{array}{c}\text { AMETYS } \\
\text { s.r.o. }\end{array}$ & $\begin{array}{c}\text { VSK MINERAL } \\
\text { s.r.o. }\end{array}$ \\
\hline $\begin{array}{l}y_{1} \text { Binding of short-term receivables } \\
y_{2} \text { Repayment period of long-term }\end{array}$ & 0.1117 & 0.0714 & 0.1513 & 0.0847 \\
liabilities & 2.1504 & 0.8876 & 2.3401 & 4.2073 \\
$y_{3}$ Operating cost indicator & 0.9109 & 1.4880 & 0.8114 & 0.9204 \\
\hline
\end{tabular}

Table 7 shows the aggregate efficiency indicator (AEI), the aggregate indicator lowering efficiency (AILE) and the synthetic indicator (SI) of the surveyed companies. The results are calculated according to the concept of the HGN model. 
Tab.7. Financial ratios and synthetic indicator

\begin{tabular}{|c|c|c|c|c|}
\hline & $\begin{array}{c}\text { EUROVIA - Kameňolomy, } \\
\text { s.r.o. } \\
\end{array}$ & $\begin{array}{c}\text { KSR - Kameňolomy SR, } \\
\text { s.r.o. }\end{array}$ & $\begin{array}{l}\text { AMETYS } \\
\text { s.r.o. }\end{array}$ & $\begin{array}{c}\text { VSK MINERAL } \\
\text { s.r.o. } \\
\end{array}$ \\
\hline$\sum_{i=1}^{3} x_{i}$ & 1.0373 & 0.7507 & 2.4299 & 0.8210 \\
\hline$\sum_{i=1} y_{i}$ & 3.1731 & 2.4470 & 3.3027 & 5.2124 \\
\hline$S U=\sum_{i=1}^{5} x_{i}-\sum_{i=1}^{5} y_{i}$ & -2.1357 & -1.6963 & -0.8729 & -4.3914 \\
\hline
\end{tabular}

The results from Table 7 show partial evaluation plus the final evaluation of efficiency with respect to the financial performance of the four companies examined. If we assess performance by partial evaluation using an aggregate efficiency indicator, we can abstract the indicators that adversely affect efficiency.

AMETYS s.r.o. has the highest efficiency in such a case. with a final coefficient of AUE of 2,4299. After taking into account the aggregate indicator reducing efficiency, i.e. evaluation by a synthetic indicator (SI), the performance of this company in comparison with other surveyed companies is still the highest despite the value of the efficiency indicator (AEI) of up to 3.3. By including the performance interval, the company will be among the average with a SU value of -0.8729 in accordance with the HGN performance intervals. It achieved quite favorable results thanks due to its low share of capital, which was significantly reflected in indicator $x_{1}$.

In this part of the paper, we will focus on the role and operation of the indicator Turnover of assets $\left(x_{3}\right)$ in the HGN model. In order to maintain the maximum objectivity of the valuation, the question may arise as to what to include in the assets for the purposes of the calculation. Should we include in the calculation of the indicator gross or net assets, i.e. after adjusting for repairs? Therefore, in Table 2 we present both gross and net assets. In Table 8 , the impact of net assets is included in the calculation of the aggregate indicator lowering efficiency (AILE). The turnover of net assets of AMETYS i calculated in this way is favorable in comparison with other examined companies. It reaches a value of 1.7 , while the other surveyed companies achieve a turnover of neither 0.56 nor 0.78 , i.e. once a year. It should also be pointed out that this company has the smallest volume of assets, while there is no significant difference in the volume of revenue achieved. The indicator Turnover of net assets reflected in the overall HGN calculation makes it possible to assess efficiency positively. Logically, the lower the volume of assets, the higher its turnover. But will it be an objective assessment? The asset turnover indicator expresses the use of total assets and depends on the nature of the industry and especially on the investment intensity. These are important factors that need to be taken into account. The type of industry is the same, but the investment intensity may be different. We evaluated only the year 2020 and therefore in this paper we abstract from the development in the time trend. A higher volume of investments in a given year may reduce, i.e. worsen, the turnover of assets.

Let's look at the behavior of the HGN model if we consider the total volume of assets, including depreciation, i.e. gross assets. Table 5 shows the indicator $x_{3}$, i.e., multiplied by three. Turnover of assets calculated from gross assets, i.e. without deduction of depreciation. The difference between these two methods of calculating the indicator shows the impact of depreciation and thus the impact of investing in the modernization and renewal of assets. Depreciated assets will cause better efficiency, that would not be a fair valuation. It is desirable to modernize and expand production by renewing assets, and this is exactly the indicator calculated from net assets would not evaluate the efficiency objectively and therefore would not evaluate the overall resulting performance of the company.

Tab. 8. Synthetic indicator calculated from net and gross assets

\begin{tabular}{|c|c|c|c|c|}
\hline & $\begin{array}{c}\text { EUROVIA - Kameňolomy, } \\
\text { s.r.o. }\end{array}$ & $\begin{array}{l}\text { KSR - Kameňolomy SR, } \\
\text { s.r.o. }\end{array}$ & $\begin{array}{c}\text { AMETYS } \\
\text { s.r.o. }\end{array}$ & $\begin{array}{l}\text { VSK MINERAL } \\
\text { s.r.o. } \\
\end{array}$ \\
\hline SI from net assets & -2.1357 & -1.6963 & -0.8729 & -4.3914 \\
\hline SI from gross assets & -2.5860 & -2.0372 & -1.6698 & -4.6055 \\
\hline Difference & 0.4503 & 0.3409 & 0.7969 & 0.2141 \\
\hline
\end{tabular}

If we include the volume of gross assets in the indicator Turnover of assets $x_{3}$, the resulting value of SU will deteriorate the most in AMETYS. If the difference between the worst and best company (valuation through HGN) based on net assets went up to 3.5, then between the worst and best company based on gross assets it is only 2.9. AMETYS will still be rated as the best, but the gap has narrowed significantly. All enterprises will continue to be in the same performance intervals, i.e., average and below average.

The asset turnover indicator is only one of the six indicators in the HGN model. The above findings obtained by the analysis of the indicator confirm the significant impact of the indicator turnover of assets $\left(x_{l}\right)$ on the final 
value of performance. And this was one of the goals of the authors of the HGN model. To enable inter alia, the use of production capacities and total assets, in particular depreciated assets. Based on the above stated information, it is essential that the calculation includes only the turnover of total assets calculated from gross assets, i.e., without taking into account depreciation, respectively, corrections. It is clearly necessary to take into account the acquisition price of the property, not its residual price. The residual price would improve turnover and thus the performance of companies with outdated technical and technological equipment.

As part of the research, we gradually verified the model in the specific conditions of companies in the Slovak Republic. We analyze the individual ratio and absolute indicators contained in the basic HGN model. The indicator $x_{3}$ will most definitely include gross assets in the basic model. This was confirmed in several analyses and also in the analysis of the four mining companies examined. Although, on the other hand, in applying the model in business practice, it is possible to adapt to your specific conditions and modify the indicators according to your needs and requirements. It is also possible to substitute the total gross assets in indicator $x_{3}$, e.g. assets without receivables or even current assets

Tab. 9. The order of performance of the surveyed companies according to the HGN model (aggregated indicators and synthetic

\begin{tabular}{c|lcclcrcr}
\hline Ord. & \multicolumn{1}{c}{ Company } & AEI* & Ord. & Company & AILE* & Ord. & Company & SI* \\
\hline 1 & AMETYS s.r.o. & 2.4299 & 1 & KSR & 2.4470 & 1 & AMETYS s.r.o. & -0.8729 \\
2 & EUROVIA & 1.0373 & 2 & EUROVIA & 3.1731 & 2 & KSR & -1.6963 \\
3 & VSK MINERAL & 0.8210 & 3 & AMETYS s.r.o. & 3.3027 & 3 & EUROVIA \\
4 & KSR & 0.7507 & 4 & VSK MINERAL & 5.2124 & 4 & VSK MINERAL & -4.1357 \\
\hline
\end{tabular}

Tab. 10. Ranking of performance of the surveyed companies according to the HGN model

\begin{tabular}{c|llclllll}
\hline Ord. & \multicolumn{1}{|c}{ Company } & AEI* & Ord. & Company & AILE* & Ord. & Company & SI* \\
\hline 1 & AMETYS s.r.o. & 1.6330 & 1 & KSR & 2.4470 & 1 & AMETYS s.r.o. & -1.6697 \\
2 & VSK MINERAL & $\mathbf{0 . 8 2 1 0}$ & 2 & EUROVIA & 3.1731 & 2 & KSR & -2.0372 \\
3 & EUROVIA & $\mathbf{0 . 5 8 7 0}$ & 3 & AMETYS s.r.o. & 3.3027 & 3 & EUROVIA \\
4 & KSR & 0.4098 & 4 & VSK MINERAL & 5.2124 & 4 & VSK MINERAL & -4.5861 \\
\hline
\end{tabular}

We compiled the order of the surveyed companies and relied on the financial performance measured by the HGN model. Table 9 contains the order according to the aggregated indicators and the synthetic indicator, taking into account the net assets in the indicator Turnover of assets $x_{3}$. Table 10 shows the order of gross assets. If we were to evaluate the performance of the surveyed companies only according to the aggregate efficiency indicator $(A E I)$, the change in the order occurred in the companies VSK MINERAL and EUROVIA. The order in the agregate indicator lowering efficiency $(A I L E)$ and in the synthetic indicator (SI) did not change. The effect of provisions on the ranking of enterprises did not significantly affect the performance, but the values of the final indicators were significantly affected by this adjustment of the content of the Turnover of assets indicator.

\section{Discussion}

The segment of the assets that has a long-term character during one accounting period does not have to mean fundamental changes, if we consider only gross assets. We can unequivocally conclude that it is more objective to take into account fixed assets in the acquisition price in the calculation and in the model without deducting depreciation.

We need to re-emphasize that in this article we are verifying the impact of the content of the indicator Turnover of asset $x_{3}$, namely the impact of net or gross assets. The volume of current assets as part of total assets is not depreciated and may change significantly during the accounting period (inventories, receivables, financial assets). We need to consider whether it will not be appropriate to eliminate some parts of the assets for the purposes of calculating the indicator Turnover of asset $x_{3}$. This issue requires a deeper analysis to enable a possible adjustment of the calculation of assets entering the indicator Turnover of assets $x_{3}$.

The value of this indicator is also significantly affected by the volume of receivables as part of the total assets. The following chart shows the share of short-term and long-term receivables of the surveyed companies according to the total volume of assets calculated from the acquisition price. 


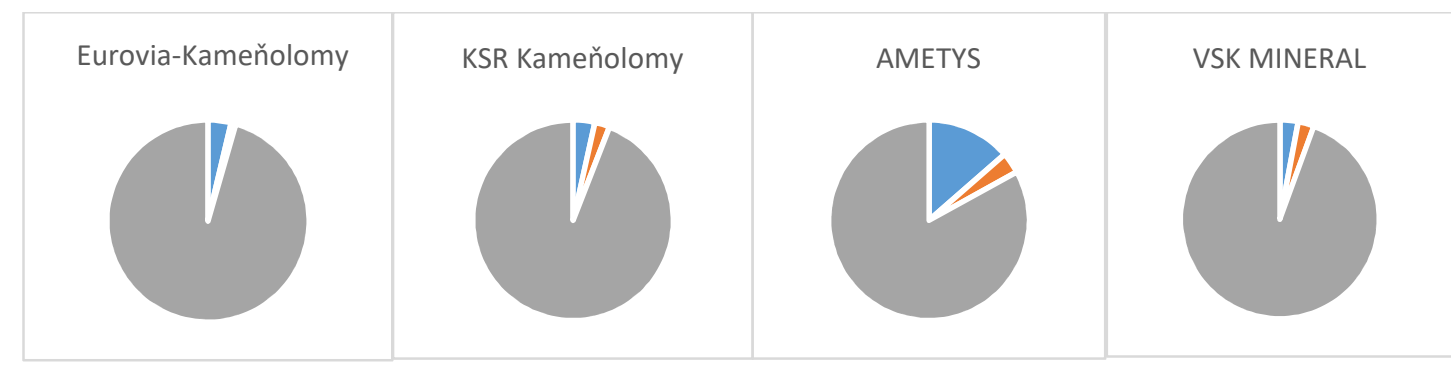

Short-term receivables, Long-term receivables, Other assets (gross)

Fig. 1. Structure of assets of selected companies

As can be seen in Figure 1, AMETYS has the highest share of receivables. Eliminating them from the total volume of assets would improve the value of the synthetic indicator. The higher the volume of receivables, the higher the volume of assets and the higher the volume of assets, the lower the value of the indicator Turnover of assets $x_{3}$. If we eliminate the volume of receivables from assets for the purposes of calculating the model, we will reduce the volume of assets and thus increase the Turnover of assets $x_{3}$. The high volume of receivables is an undesirable factor that worsens the cash flow and may have an adverse effect on the overall financial situation of the company due to the inability to repay debts. The exclusion of property receivables for the calculation of HGN would not contribute to an objective assessment of performance.

\section{Conclusions}

In the previous research, when comparing the HGN model and the Altman Z-score by applying it to the data of restructured companies, we found more objective results in the predictive ability of the HGN model. In this article we do not evaluate the financial performance of selected companies in the time horizon. We verify the HGN model only for the particular time period of one accounting period, namely data from publicly available financial statements for the year 2020. We abstract from the predictive ability of the HGN model. We focused on the potential possibilities of modifying one of the indicators affecting efficiency as part of the evaluation of the company's financial performance by applying it to selected companies in the mining industry. The hypothesis of the need to include the asset in its total volume in its acquisition price was confirmed. Based on the above, this is vitally important for a more objective assessment of efficiency and for better comparisons between companies. The residual price would improve turnover and thus the performance of companies with outdated technical and technological equipment. The Turnover of Assets $x_{3}$ indicator implies a number of absolute data determining the final efficiency results. We gradually analyze these absolute data and verify their impact on the overall financial performance of the company. More fundamental changes in the content of some indicators entering the HGN model will also require a reassessment of the performance interval. In this paper, we have assessed only the impact of assets on the acquisition and residual value, while changes in the performance scale as shown in Table 1 will not have any impact.

\section{References}

Altman, E. I., \& Saunders, A. (1997). Credit risk measurement: Developments over the last 20 years. Journal of banking \& finance, 21(11-12), 1721-1742.

Andryeyeva, N., Nikishyna, O., Burkynskyi, B., Khumarova, N., Laiko, O., \& Tiutiunnyk, H. (2021). Methodology of analysis of the influence of the economic policy of the state on the environment. Insights into Regional Development, 3(2), 198-212. https://doi.org/10.9770/IRD.2021.3.2(3)

Baatartogtokh, B., Dunbar, W. S., van Zyl, D. (2018). The state of outsourcing in the Canadian mining industry. Resource Policy, 59, 184-191.

Bacik, R., Fedorko, R., Abbas, E. W., Rigelsky, M., Ivankova, V., \& Obsatnikova, K. (2019). The impact of selected quality management attributes on the profitability of TOP hotels in the Visegrad group countries. Polish Journal of Management Studies, 19(1), 46-58. https://doi.org/10.17512/pjms.2019.19.1.04

Belas, J., Cepel, M., Gavurova, B., \& Kmecová, I. (2020). Impact of social factors on formation of business environment for SMEs. Economics \& Sociology, 13(4), 267-280. https://doi.org/10.14254/2071789X.2020/13-4/17

Čabinová, V., Gallo, P., Pártlová, P., Dobrovič, J.\&Stoch, M.(2021). Evaluating Business Performance and Efficiency in the Medical Tourism: AMulti-criteria Approach. Journal of Tourism and Services,22(12), 198-221. https://doi.org/10.29036/jots.v12i22.247 
Çera, G., Belas, J., Marousek, J., \& Çera, E. (2020). Do size and age of small and medium-sized enterprises matter in corporate social responsibility? Economics \& Sociology, 13(2), 86-99. https://doi.org/10.14254/2071789X.2020/13-2/6

Civelek, M., Gajdka, K., Světlík, J., \& Vavrečka, V. (2020). Differences in the usage of online marketing and social media tools: evidence from Czech, Slovakian and Hungarian SMEs. Equilibrium. Quarterly Journal of Economics and Economic Policy, 15(3), 537-563. https://doi.org/10.24136/eq.2020.024

Civelek, M., Ključnikov, A., Fialova, V., Folvarčná, A., \& Stoch, M. (2021). How innovativeness of family-owned SMEs differ depending on their characteristics? Equilibrium. Quarterly Journal of Economics and Economic Policy, 16(2), 413-428. https://doi.org/10.24136/eq.2021 .015

Čižo, E., Lavrinenko, O., \& Ignatjeva, S. (2020). Analysis of the relationship between financial development and economic growth in the EU countries. Insights into Regional Development, 2(3), 645-660. https://doi.org/10.9770/IRD.2020.2.3(3)

Dvorsky, J., Belas, J. Jr., Cera, G., \& Bilan, S. (2021a). Disparities in the perception of business risks in connection with the achieved education of the owner/manager and doing business. International Journal of Entrepreneurial Knowledge, 9(1), 25-40. https://doi.org/10.37335/ijek.v9i1.123

Dvorsky, J., Belas, J., Gavurova, B., \& Brabenec, T. (2021b). Business risk management in the context of small and medium-sized enterprises. Economic Research-Ekonomska Istraživanja, 34(1), 1690-1708. https://doi.org/10.1080/1331677X.2020.1844588

Dvorský, J., Petráková, Z., \& Polách, J. (2019). Assessing the Market, Financial, and Economic Risk Sources by Czech and Slovak SMEs. International Journal of Entrepreneurial Knowledge, 7(2), 30-40. https://doi.org/10.12345-0008

Fanta, M. (2019). Water management in the Czech Republic: Transformation, restructuralization, and comparison of the current state of the branch with the state in 1993. Littera Scripta, 12(1), 16-27.

Gavurova, B., Cepel, M., Belas, J., \& Dvorsky, J. (2020). Strategic management in SMEs and its significance for enhancing the competitiveness in the V4 countries - A comparative analysis. Management \& Marketing. Challenges for the Knowledge Society, 15(4), 557-569. https://doi.org/10.2478/mmcks-2020-0032

Gavurova, B., Privara, A., Janikova, J., \& Kovac, V. (2021). Quantification of tourism sector parameters related to competitiveness of countries according to macroeconomic indicators. Journal of Competitiveness, 13(3), 56-72. https://doi.org/10.7441/joc.2021.03.04

Grell, M., \& Hyránek, E. (2012). Maticové modely na meranie výkonnosti produkčných systémov. $E+M$. Ekonomie a management. 15(1), 73-87.

Halaskova, M., Gavurova, B., \& Korony, S. (2020). Change of EU28 countries research and development indicators between 2010 and 2015. Economics \& Sociology, 13(1), 230-248. https://doi.org/10.14254/2071789X.2020/13-1/15

He, Y., Sheng, P., \& Vochozka, M. (2017). Pollution caused by finance and the relative policy analysis in China. Energy \& Environment, 28(7), 808-823.

Horak J., Vrbka J., \& Suler P. (2020). Support vector machine methods and artificial neural networks used for the development of bankruptcy prediction models and their comparison. Journal of Risk and Financial Management. 13(3), 60. https://doi.org/10.3390/jrfm13030060

Hyránek, E. (2012). Application of Altman's Z-score in benchmarking. Proceedings of scientific articles: results of solving the grant task VEGA no. 1/0754/11, VEGA no. 1/0187/11, VEGA no. 1/1071/12. Bratislava: Publishing house EKONÓM, pp. 61-66. ISBN 978-80-225-3540-3.

Hyránek, E. Grell, M. \& Nagy, L. (2014). New trends in measuring business performance for financial decisions.1st ed. Bratislava: Publishing house EKONÓM, 2014. ISBN 978-80-225-3901-2.

Hyránek, E. Grell, M. \& Nagy, L. (2017). Implementation of the performance model in financial decision-making of the company: the HGN model as a tool of financial plan. 1st ed. Praha: Nakladatelství Baset, 2017. 192 p. ISBN 978-80-7340-173-3.

Hyránek, E. Grell, M. Nagy, L. \& Durinová, I. (2018). The Economic-Mathematical Nature of the HGN Model Concept as a Tool for Measuring Performance of Enterprises. Ekonomický Časopis, 66(3), 309-325.

Horvath, J., Gavurova, B., Bacik, R. \& Fedorko, R. (2021). Identification of Uncertainty Factors in the Consumer Behaviourof the New Generation of Customers at the E-commerce Level. Journal of Tourism and Services, 22(12), 168-183. https://doi.org/10.29036/jots.v12i22.263

Janovac, T., Virijević Jovanović, S., Tadić, J., Tomić, G., Cufalić, S. (2021). The influence of employee motivation factors on job satisfaction in mining companies. Polish Journal of Management Studies, 23(1), 224-238. DOI: 10.17512/pjms.2021.23.1.14

Jurásek, M., Petrů, N., Caha, Z. \& Belas, J. (2021). Values of family businesses in Czech Republic in the context of socioemotional wealth. Economics \& Sociology, 14(2), 184-208. https://doi.org/10.14254/2071789X.2021/14-2/10 
Kasych, A., Rowland, Z., \& Yakovenko, Y. (2019). Modern management tools for sustainable development of mining enterprises. Proccedings of E3S Web of Conferences: Ukrainian School of Mining Engineering 2019, Berdiansk, Ukraine, 3-7 September 2019.

Kearney, H., Kliestik, T., Kovacova, M., \& Vochozka, M. (2019). The embedding of smart digital technolgies within urban infrastructures: Governance networks, real-time data sustainability, and the cognitive internet of things. Geopolotics, History, and International Realtions, 11(1), 98-103.

Kliestik T., Nica E., Suler P., \& Valaskova K. (2020). Innovations in the company's earnings management: The case for the Czech Republic and Slovakia. Marketing and Management of Innovations, 3, 332-345.

Ključnikov, A., Civelek, M., Čech, P., \& Kloudová, J. (2019). Entrepreneur ial orientation of SMEs' executives in the comparative perspective for Czechia and Turkey. Oeconomia Copernicana, 10(4), 773-795. https://doi.org/10.24136/oc.2019.035

Ključnikov, A., Civelek, M., Fialova, V., \& Folvarčná, A. (2021). Organizational, local, and global innovativeness of family-owned SMEs depending on firm-individual level characteristics: evidence from the Czech Republic. Equilibrium. Quarterly Journal of Economics and Economic Policy, 16(1), 169-184. https://doi.org/10.24136/eq.2021.006

Ključnikov, A., Civelek, M., Polách, J., Mikoláš, Z., \& Banot, M. (2020a). How do security and benefits instill trustworthiness of a digital local currency? Oeconomia Copernicana, 11(3), 433-465. https://doi.org/10.24136/oc.2020.018

Ključnikov, A., Civelek, M., Vozňáková, I., \& Krajčík, V. (2020b). Can discounts expand local and digital currency awareness of individuals depending on their characteristics? Oeconomia Copernicana, 11(2), 239-266. https://doi.org/10.24136/oc.2020.010

Kuzmanovic, M., Panic, B., Vujosevic, M., \& Vujic, S. (2011). Risk Assessment and management in the Mining Industry. In: Stirn, L. Z., Zerovnik, J., Povh, J., Drobne, S., Lisec, A. (Eds.) 11th International Symposium on Operational Research (SOR '11), Dolenjske Toplice, Slovenia, 28-30 September 2011, pp. 245-250.

Ludbrook F., Michalikova K.F., Musova Z., \& Suler P. (2019). Business Models for Sustainable Innovation in Industry 4.0: Smart Manufacturing Processes, Digitalization of Production Systems, and Data-driven Decision Making. Journal of Self-Governance and Management Economics, 7(3), 21-26. https://doi.org/10.22381/JSME7320193.

Machova V., Vochozka M. (2019). Using artificial intelligence in analysing and predicting the development of stock prices of a subject company. Sustainable Growth and Development of Economic Systems: Contradictions in the Era of Digitalization and Globalization, In: Contributions to Economics. Cham, Switzerland: Springer, pp. 235-245.

Metzker, Z., \& Zvarikova, K. (2021). The Perception of Company Employees by SMEs with CSR Concept Implementation. International Journal of Entrepreneurial Knowledge, 9(1), 81-96. https://doi.org/10.37335/ijek.v9i1.128

Moczulski, W., Przystalka, P., Sikora, M., Zimoroz, R. (2016). Modern ICT and Mechatronic Systems in Contemporary Mining Industry. In: Flores, V., Gomide, F., Janusz, A., Meneses, C., Miao, D., Peters, G., Slezak, D., Wang, G., Weber, R, Yao, Y. (Eds.) International Joint Conference on Rough Sets (IJCRS), Univ Chile, Santiago, Chile, 7-11 October 2016, vol. 9920, pp. 33-42.

Nassar, N., \& Tvaronavičienè, M. (2021). A systematic theoretical review on sustainable management for green competitiveness. Insights into Regional Development, 3(2), 267-281. https://doi.org/10.9770/IRD.2021.3.2(7)

Okpamen, H., \& Ogbeide, S. O. (2020). Board director reputation capital and financial performance of listed firms in Nigeria. Insights into Regional Development, 2(4), 765-773. http://doi.org/10.9770/IRD.2020.2.4(3)

Pana, L., Grabara, J., Pasculescu, D., Pasculescu, V.M., Moraru, R.I. (2018). Optimal quality management algorithm for assessing the usage capacity level of mining transformers. Polish Journal of Management Studies, 18(2), 233-244. DOI: 10.17512/pjms.2018.18.2.19

Přívara, A., Rievajová, E., \& Barbulescu, A. (2020). Attracting high skilled individuals in the EU: The Finnish experience. Migration Letters, 17(2), 369-377. https://doi.org/10.33182/ml.v17i2.927

Ranangen, H., \& Lindman, A. (2017). A path towards sustainability for the Nordic mining industry. Journal of Cleaner Production, 151, 43-52.

Rebhun, U. (2021). Inter-country variations in COVID-19 incidence from a social science perspective. Migration Letters, 18(4), 413-423. https://doi.org/10.33182/ml.v18i4.1254

Sagapova, N., \& Gulyas, J. (2021). The development of the financial health within the fishing industry in the South Bohemian region. Littera Scripta, 14(1), 123-134. ISSN 1805-9112.

Sanchez, F., \& Hartlieb, P. (2020). Innovation in the Mining Industry: Technological Trends and a Case Study of the Challenges of Disruptive Innovation. Mining Metalurgy \& Exploration, 37(5), 1385-1399.

Sierpinska, M., \& Kustra, A., (2008). Bonus systems in mining industry. Current situation and future developments. Gospodarka Surowcami Mineralnymi-Mineral Resources Management, 24(4), 223-235. 
Stefko, R., Gavurova, B., Kelemen, M., Rigelsky, M., \& Ivankova, V. (2021). Relationships between renewable energy and the prevalence of morbidity in the countries of the European Union: A panel regression approach. International Journal of Environmental Research and Public Health, 18(12), 6548. https://doi.org/10.3390/ijerph18126548

Štefko, R., Jenčová, S., \& Vašaničová, P. (2020). The Slovak spa industry and spa companies: Financial and economic situation. Journal of Tourism and Services, 20(11), 28-43. https://doi.org/10.29036/jots.v11i20.137

Suler, P., Horak, J., \& Krulicky, T. (2020). Validation of the prediction of ČEZ stock prices. Littera Scripta, 13(1), 194-210.

Suler P., Palmer L., \& Bilan S. (2021). Internet of Things sensing networks, digitized mass production, and sustainable organizational performance in Cyber-Physical system-based smart factories. Journal of SelfGovernance and Management Economics, 9(2), 42-51.

Tubis, A., Werbinska-Wojciechowska, S., \& Wroblewski, A. (2020). Risk Assessment Methods in Mining Industry-A Systematic Review. Applied Sciences-Basel, 10(15), 5172.

Vochozka, M., Horak, J., \& Krulicky, T. (2020a). Innovations in management forecast: Time development of stock prices with neural networks. Marketing and Management of Innovations, 2020(2), 324-339.

Vochozka, M., \& Psarska, M. (2016). Factors supporting growth of added value, performance and competitivness of SMEs and selected EU countries. In Innovation Management Entrepreneurship and Corporate Sustainability 2016, Prague, Czech Republic, pp. 756-767.

Vochozka M., Rowland Z., \& Vrbka J. (2016). Financial analysis of an average transport company in the Czech Republic. Nase More, 63(3), 227-236.

Vochozka M., Vrbka J., \& Suler P. (2020b). Bankruptcy or success? The effective prediction of a company's financial development using LSTM. Sustainability, 12(18), 7529. https://doi.org/10.3390/su12187529

Vokoun, M. (2017). Issues Inside the Field of Economics of Innovation: Definitions, Data Sources, Estimation Procedures and Comparability of Results. Littera Scripta, 10(2), 165-176.

Vrbka, J., \& Rowland, Z. (2019). Assessing of financial health of companies engaged in mining and extraction using methods of complex evaluation of enterprises. In Sustainable Growth and Development of Economic Systems: Contradictions in the Era of Digitalization and Globalization, In: Contributions to Economics, Cham, Switzerland, pp. 321-333.

Whittle T., Gregova E., Podhorska I., \& Rowland Z. (2019). Smart manufacturing technologies: Data-driven algorithms in production planning, sustainable value creation, and operational performance improvement. Economics, Management, and Financial Markets, 14(2), 52-57. https://doi.org/10.22381/EMFM14220193.

Zheng, A. H., \& Li, N. (2008). The effect of coal mine disasters on the coal industry in China. Proccedings of the 3rd International Symposium on Modern Mining and Safety Technology, Liaoning Tech Univ, Fuxin, PRC, 4-6 August 2008, pp. 607-612.

Zhou, Q. (2013). Mining environment governance and sustainable development of coal industry. In: Zheng, J. M., Zhu, H. X., Kong, J. Y (Eds.) 2nd International Conference on Chemical, Material and Metallurgical Engineering (ICCMME 2012), 634-638, 3423-3427. ISSN 1022-6680. 